Responses to Volatile Capital Flows: Controls, Asset Liability Management and Architecture

Michael P. Dooley

Presented at World Bank/ International Monetary Fund/World Trade Organization, Conference on Capital Flows, Financial Crises, and Policies, April 15-16, 1999. 
Responses to Volatile Capital Flows: Controls, Asset-Liability Management, and Architecture.

Introduction

Before setting out a menu of governments' responses to international capital flows it is worth reminding ourselves that we have little hard evidence that any feasible intervention would improve economic welfare. We know that developing countries that have opened their financial markets have not been able to avoid financial crises and these crises are quite costly in terms of large and persistent losses in output. We also know that countries that have not opened their capital markets have avoided crises but have also avoided the rapid economic growth that countries with open markets have enjoyed between crises. We cannot rank these policies because we do not know enough about what went wrong with the experiments with market forces. Nor do we have very clear idea about the costs of financial repression.

A "whole cloth" approach to evaluating governments' interventions in financial markets is unlikely to be convincing to either side. Countries with repressed financial systems will continue to congratulate themselves on their stability as international markets collapse. Free marketers will continue to believe that "in the long run" crises weed out the weak and set the stage for the next burst of growth and development.

In this paper I follow a much more restrictive approach to evaluating potential interventions in international capital markets. The focus is on one possible source of market failure and alternative interventions that might mitigate the assumed damage done by this distortion. The objective is to try to evaluate marginal adjustments to free markets in order to evaluate the claim that "small" government interventions can improve the incentive structure faced by private international investors.

The distortion is generated by the inability of governments to credibly commit to allowing large financial institutions and large domestic firms to fail. This is an interesting distortion for several reasons. First, it has shaped much of the government intervention in domestic financial markets in industrial countries. Moreover, as industrial countries opened their financial markets to international capital flows in the 1970s and 80s, regulatory mechanisms were adapted to the challenges generated by international capital flows. These adaptations have been largely successful in the developed countries. But it is now clear that while governments of developing countries suffer the same inability to stay out of the game when private debts go bad, they have been much less successful in adapting to open capital markets. 
It is important, therefore, to explore policy interventions better suited to the political and administrative constraints faced by governments of developing countries. In my view such alternatives may be necessary to support a regime in which residents of these countries participate in the international financial system. The objective is to set out a policy regime that is market oriented but that reduces the costs of crises from current levels.

The plan of the paper is as follows. In the next section we motivate the distortion focused on with a simple "insurance" model of capital flows and crises. We then evaluate three remedial interventions. The first is an "entry tax" on capital inflows. The second is a debt and asset management policy for governments of developing countries designed to avoid crises. The third is a change in policies in developing countries and the "architecture" of international capital markets that is designed to reduce the costs of crises.

The anatomy of an insurance crisis.

The distortion in the model outlined in this section is generated by the desire of a creditconstrained government to hold reserve assets as a form of self-insurance and the government's inability to credibly commit not to liquidate these assets in order to lend to domestic financial and nonfinancial firms. This policy regime generates incentives for investors to acquire insured claims on residents and to then acquire the government's assets when yield differentials make this optimal. The credit constraint faced by governments of developing countries is important in determining the incentives faced by private investors and the timing of their international investment decisions.

A key feature of the model is that free insurance raises the market yield on a set of liabilities issued by residents for a predictable time period. This yield differential generates a private gross capital inflow (a sale of domestic liabilities to nonresidents) that continues until the day of attack. The private inflow is necessarily associated with some combination of an increase in the government's international reserve assets, a current account deficit and a gross private capital outflow. When the government's reserves are exactly matched by its contingent insurance liabilities, the expected yield on domestic liabilities falls below market rates and investors sell the insured assets to the government, exhausting its reserves. The speculative attack is fully anticipated and at the time of the attack nothing special happens to the fundamentals or expectations about the fundamentals.

This sequence of events is illustrated in Figure 1. The positive vertical axis in the top panel measures the stock of assets the government, including the central bank, is expected to liquidate during a crisis in order to redeem liabilities to the private sector. The negative vertical axis measures the government's total stock of contingent and noncontingent liabilities. We start from a situation in which the value of assets, $A_{0}$, is growing but is less than $L_{0}$ the value of debt. ${ }^{1}$

\footnotetext{
${ }^{1}$ The market value of the debt would be equal to the collateral value. That is, there would be a secondary market price discount. See Dooley et al. (1996) for a model and evidence.
} 
A fall in international interest rates at $t_{1}$ reduces the value of government's long term liabilities from $L_{0}$ to $L_{1}$, but does not affect the contractual value of short term assets. A part of the government's assets can now support additional liabilities.

The critical difference between industrial and developing countries is not the nature of the insurance distortion but the conditions under which the insurance is credible. For industrial countries it is reasonable to assume that the government can always borrow in order to honor implicit or explicit insurance commitments. Thus, governments of industrial countries must always monitor and discourage efforts by the private sector to exploit the insurance.

For governments of developing countries it is reasonable to assume that they will face market interest rates in the midst of a crisis that make borrowing unattractive or infeasible. It follows that their insurance commitments are credible only if they have assets, or lines of credit with predetermined interest rates, that can be liquidated to support the insurance. The interesting problem is that insurance and ineffective monitoring of the private sector does not generate a distortion all the time but only when the government has acquired assets. Moreover the distortion will not last for a long time because the private sector will immediately set out to capture assets acquired by the government.

In the middle panel we illustrate this process. At $t_{1}$ a capital gain on existing government liabilities or assets generates a net liquid asset position for the government. Residents that can issue an insured liability will now offer to do so in order to appropriate some share " $s$ " of the proceeds ${ }^{2}$. Appropriation is any activity that benefits the intermediary at the expense of asset values. For example, governments that control intermediaries might instruct them to lend to firms that do not earn the competitive rate of interest in order to promote exports or employment. Or the resident that issues the insured liability might appropriate some share of the proceeds and invest them offshore. Sellers of such liabilities are residents simply because only residents' liabilities are eligible for insurance. The government's contingent liability is the same fraction of new insured liabilities (the shaded area in the middle panel).

The value of $s$ is specific to the country and is small in a well-regulated market and large in a poorly regulated market. The time derivative of the flow of new issues (the slope of $P L$ ) is also specific to each country and is also a function of the supervisory system in place. Relatively poorly regulated financial markets will see a relatively rapid increase in insured liabilities ${ }^{3}$.

${ }^{2} \mathrm{~A}$ more realistic form of appropriation is state contingent. That is, insured residents exploit insurance by reaching for risk. They share returns earned in good states of the world and default in bad states of the world.

3 We assume in this example that the growth in liabilities is greater than the growth in assets but this is clearly an empirical issue. An important difference between emerging markets and industrial countries is that the governments in industrial countries constrain domestic intermediaries before the government's net worth is exhausted. Thus, in the US savings and loan crisis there was no run on the government's reserves. Instead a binding constraint was established 
Investors are willing to buy residents' liabilities because they are insured and because competition among (resident) sellers will force them to share a part of their appropriation with (nonresident) creditors. This will take the form of above market expected yields on residents' liabilities ${ }^{4}$. Yields will be the same for both domestic currency and foreign currency liabilities of residents as long as the insurance is expected to cover both types of domestic liabilities. ${ }^{5}$

As long as the" foreign" investors earn above market yields there is a disincentive for an attack on the government's assets. Investors will prefer to hold the growing stock of high yield insured liabilities of residents and allow the government to hold reserves that earn the risk free rate $^{6}$. Private profits are realized before the attack. The attack itself is generated by competition to avoid losses. When the contingent liabilities of the government are just equal to liquid assets (

by reregulating the financial system. The resulting loss to the government was substantial but well within its ability to provide credible insurance.

${ }^{4}$ The accounting is straightforward if we abstract from financial intermediation. Suppose a resident household can issue a $\$ 10$ liability to a foreign investor. The household plans on repaying $\$ 5$. The household shares its gain by paying the investor $\$ 2.50$ and keeping $\$ 2.50$. The investor expects the government to purchase the liability for $\$ 10$ in one year. The government's contingent liability is $\$ 5.00$. More realistic examples will involve one or more financial intermediaries in this process. The distribution of the rents among the participants will depend on their relative bargaining power. If investors' demand for claims on residents are very elastic, residents will capture most of the rents. This seems to us the most likely outcome. It is difficult to interpret historical evidence for deposit rates. As insurance became credible after 1989 deposit rates should have fallen as default risk was absorbed by the government. In Mexico real ex post rates on domestic deposits (adjusted for actual changes in dollar exchange rates) fell from about 15 percent above US rates in 1990 to equality with US rates in late 1994. While this pattern in returns is consistent with our model, Mexico's stabilization program may have had important implications for this history of yield differentials.

${ }^{5}$ If the insurance is only available on domestic (foreign currency) liabilities an equilibrium covered interest differential will emerge in favor of domestic (foreign currency) liabilities. A fixed exchange rate regime is not crucial for the argument. Under floating exchange rates the nonresident investor plans to liquidate her position at the time of the anticipated attack. It follows that any spot foreign exchange transactions will be offset by a matching forward exchange transaction. Private interest arbitrage will ensure that there is no net change in spot or forward rates.

6 In most emerging markets the capital inflows have been partially sterilized so that gross reserve assets also begin to grow more rapidly at $\mathrm{t}_{1}$. However, the government must issue domestic currency debt to finance the purchase of reserves. In this simple example we assume that sterilized intervention does not add to the net stock of liquid assets expected to be exhausted at the time of attack. A more realistic treatment of the relative seniority of alternative government liabilities and expected capital gains and losses on gross positions would not change the qualitative results of the model. 
$\underline{A}_{2}=\underline{L}_{2} L_{\text {, }}$ competition among investors will insure that all will "call" the insurance option.

The bottom panel of Figure 1 reflects the assumption that nonresidents demand a constant premium in order to accumulate insured deposits. On the day of the attack the expected value of this premium becomes negative because each depositor's share of the insurance pool will begin to shrink. Resident borrowers will continue to appropriate a part of new loans and this will depress expected yields on deposits that after $\mathrm{t}_{1}$ are only partially insured.

Following an attack the regime returns to its initial equilibrium in which the government's net international reserves have returned to zero. The crisis does nothing to resolve the underlying policy conflict. Following the crisis the government will once again attempt to accumulate liquid assets and unexpected capital gains and losses on the governments' asset position will eventually generate a new inflow/attack sequence.

\section{Capital controls.}

A recurring theme in discussions of recent crises is the view that noise traders and other types of pathological speculation are the source of the problem. While we do not find this particular hypothesis convincing, it has led discussion and adoption of a specific form of intervention that is highly relevant for the insurance model. The key feature of this government intervention is that it is designed to tax relatively heavily capital inflows that are held for short periods of time.

The well known Tobin Tax proposal was based on the idea that inefficient speculation is dominated by traders that move in and out of the market more frequently than could be "reasonably" associated with changes in expectations about the fundamentals.

"The hope that transactions taxes will diminish excess volatility depends on the likelihood that Keynes's speculators have shorter time horizons and holding periods than market participants engaged in long-term foreign investment and otherwise oriented toward fundamentals. If so, it is speculators who are the more deterred by the tax."

This is a sensible conjecture but does not stand up to empirical evaluation. Dooley (1998a) argues that there is no evidence that favors the assumption that high transactions costs tend to deter noise traders relative to investors that evaluate fundamentals and there is some weak evidence to the contrary. Perhaps more important, there is considerable doubt that reducing the variability of prices generates increases in welfare since the turnover tax tends to increase the volatility of expected yields on taxed assets.

7 Eichengreen, Tobin and Wyplosz (1995) 
The insurance model outlined above does suggest that welfare reducing capital flows might be taxed more heavily by a transaction tax, or its close relative, an entry tax, on capital flows to a developing country. Moreover, an entry tax is much less subject to evasion since a comprehensive tax on capital inflows cannot be easily avoided through derivative transactions. Capital inflows motivated by an insurance policy have a known--and probably short--expected holding period. The model suggests that relatively poorly regulated financial systems will experience large capital inflows following an increase in the government's stock of liquid assets or an opening of the financial system. This idea is supported by the data presented in Chart 1 that relates a measure of corruption to the length of the capital inflow phases of inflow/crises sequences for a sample of emerging markets.

The model also suggests that the capital inflow/crisis sequence depends on the condition that the resident can appropriate more than must be paid to the nonresident investor to increase his claims on residents of the developing country. Other things equal an increase in the spread demanded by nonresidents to hold domestic deposits reduces the profitability of exploiting insurance for the resident bank or firm. There is an interesting interaction here in that the entry tax necessary to stop an inflow crisis sequence is higher if the profitability of appropriation is high but is lower if the inflow crisis sequence is short. This is because investors enjoy unusual returns only during the inflow phase of the sequence.

\section{Debt and Asset Management}

Macroeconomic analysis and other first generation models of speculative attacks emphasize fiscal deficits as the main driving force behind changes in governments' outstanding stocks of net debt. This is a bit surprising in light of the easily compiled evidence to the contrary. In the series of Charts presented below we illustrate two important empirical regularities for the public finances of developing countries. First, central governments' expenditures and tax receipts and their differences, fiscal deficits, are very predictable and are very persistent over time. In each chart we show the actual fiscal deficit as a percent of GDP and the predicted deficit where the predicted deficit is derived from fitted values for receipts and expenditures. Annual values for central government expenditures and receipts, expressed as a share of GDP, are related to only four or five variables including international interest rates, domestic interest rates, oil prices, a domestic output gap, and in some cases an election cycle dummy.

The integral of the fitted and actual deficits is shown in the top panel of each chart. The overwhelming result is that debt from fiscal imbalances is predictable. Moreover, shocks to either series are very persistent over the sample period.

In the top panel of each chart is also shown the recorded stock of internal plus external debt for each country less that share of debt held by the monetary authorities. If there were no capital gains and losses or other off balance sheet additions to debt, the stock of debt should be equal to the integral of the deficits. It clearly is not and the deviations are in many cases larger than the accumulated deficits. The shaded area in each panel provides a visual impression of the 
“alligator's mouth" that has swallowed the financial health of many of these countries.

Where did this debt come from? Each country is a case study but there are some common features. In many cases governments have issued debt to bail out domestic banking systems where losses overnight added debt equal to 10-30 percent of GDP. Central governments have refinanced debt of state and local governments adding to their own debt. On the other side governments have sold state owned industries and reduced outstanding debt.

In our simple model governments passively allow capital gains to augment liquid reserves and hold those reserves in order to smooth consumption. A more realistic assessment of the behavior of governments suggests that they manage their asset and liability portfolios to meet a large number of objectives. Governments have a variety of reasons to engage in financial intermediation. But while benefits are often associated with individual activities, costs generated by financial crises are related to the contribution of each activity to the government's exposure to crises. A "good" portfolio is one which balances the welfare gains from each activity with the costs generated by that activity's contribution to conditions that will generate a crisis. The formal literature on debt management policy is dominated by models appropriate for industrial countries. In these models the government is usually seen as a superior financial intermediary that can, for some reason, carry out welfare improving intertemporal or intergenerational trades that the private sector cannot. But this literature also assumes that the government remains solvent. This is not an appropriate assumption for developing countries.

The "right" balance sheet to manage depends on the economic model behind the analysis. Because our model suggests that crises follow changes in market value of the government's assets and liabilities, we need to construct a detailed balance sheet that is informative about the conditions under which changes in the government's ability to insure sets the stage for a crisis.

The portfolio of foreign-currency-denominated financial assets and liabilities that is typically actively managed is just the tip of the iceberg. Governments issue many types of debt, acquire many types of assets and do so for a bewildering array of reasons. Important examples of financial intermediation include domestic borrowing to finance fiscal deficits, foreign exchange market intervention, deposit insurance, lender of last resort commitments, membership in international organizations, social insurance commitments, and direct ownership of resources and state enterprises.

Industrial country governments have generally been very conservative in limiting their scale of financial intermediation. This probably reflects sensitivity to the political problems associated with capital gains and losses generated by highly leveraged positions. For example, the relative unwillingness of the government of the United States to intervene in foreign exchange markets is partly explained by the unwillingness of the Treasury and Federal Reserve to accumulate reserve assets that fluctuate in value relative to the domestic currency debt that necessarily finances such accumulations.

Developing country governments have been much more inclined to leverage their positions. Sterilized intervention for example has created large asset and liability positions that 
are sensitive to exchange rate changes. Moreover, governments in developing countries are probably more exposed to capital gains and losses than they realize. At a minimum, governments that manage exchange rates must consider the implicit liability to guarantee the domestic currency value of assets and liabilities in the domestic banking system. If a government decides to liberalize its domestic credit markets, prudent debt management policy would immediately recognize an implicit liability that will arise if important institutions prove not viable in this new environment. If the insured institutions are sensitive to increases in international interest rates, it is important that the government's other liabilities not be sensitive to these factors.

A few practical suggestions emerge from these considerations. A conservative flow fiscal policy is clearly not enough to protect the country from crises spawned by government finances. Developing countries should probably avoid sterilized intervention. This is one rationale for the growing consensus that "in between" exchange rate regimes are not viable. Floating exchange rate regimes are robust for two reasons. First, they limit the government's lender of last resort commitment to the maintenance of the domestic currency value of bank assets. Second, floating minimizes the accumulation of foreign exchange assets. Currency boards can also be robust if the lender of last resort commitment is credibly limited by the restrictions on the government's ability to intervene to stop a domestic financial crisis.

\section{Architecture}

The simple model described in the first section does not provide an explanation for the output losses that have followed crises. But the discussion of governments' extended balance sheets suggests that when a crisis comes not all investors in developing countries will be protected. Moreover, the simple model assumes that all claims on government resources are settled immediately and without conflict. An important extension of the model recognizes that governments can borrow from some creditors without insurance. For example, international organizations might lend to support policy reforms. Moreover, if the government could borrow from residents even if residents expect not to be insured in the event of a crisis we would add this credit line to that available from the official sector in order to calculate net assets. In general access to domestic credit or credits from foreign governments or international organizations can make insurance for nonresident investors more credible and can influence the negotiations among creditors following crises.

There are many possible reasons for the loss in output that might follow an attack on the governments' assets. For example, the private information that makes most financial intermediation possible may be less useful in an environment where the government's treatment of its creditors and taxpayers is uncertain. In this next section we take up the important question of how debtor governments' policies and the architecture of the international monetary system might be altered to reduce these costs.

We define default as the interval following an attack on the government's resources during which creditors compete for repayment without an agreement concerning the terms of 
repayment. If the government is in default for a few minutes, it is reasonable to assume that there is no loss in economic welfare. But recent experience suggests that default, as we define it, can last for several years following a crisis. Note that this definition of default is unrelated to the usual definition of present value solvency. Solvent governments can and have been in default. Two policy interventions might shorten this interval and the associated costs.

A systemic response, what has been called improving the architecture of international finance, is perhaps the most ambitious. This type of intervention would alter the rules of the game for private international finance. This intervention is appealing because it goes right to the source of the welfare losses generated by financial crises. Defaults are costly for both debtors and creditors. The loss of output that follows financial crises benefits no one.

The more interesting proposals for reforming the system focus on the costs of financial crises and propose alternative ways to clean up the mess after a crisis. An important insight from this literature is that simple financial contracts actually used in international finance will never be able to cover all contingencies and that default will be a part of an efficient system. The problem is that mechanisms for resolving defaults that make domestic financial markets more efficient are not available for cross border debt. It seems clear therefore that a more predictable procedure for renegotiating contracts would reduce the costs of financial crises. A predictable result might be generated by a bankruptcy court or by changes in contracts that alter the bargaining power of debtors or creditors in the event of default.

This line of thought is particularly interesting to creditor governments because they are often called upon to smooth renegotiations between private creditors and debtor governments by making side payments to private creditors. This usually takes the form of lending to debtor governments on better than market terms after the crisis. It is natural for official creditors to want to "bail in" private lenders as a quid pro quo for such assistance.

In our view the problem with this approach is that the threat of losses in output may be a necessary incentive for repayment. This basic feature of private international lending is a serious obstacle to reform of the international monetary system. Developing countries want to commit themselves to repayment because this allows access to international capital markets. But neither the debtor nor the creditor gains from imposing the costs associated with international default.

Indeed, individual creditors may not want to impose the costs associated with default but are forced to do so to protect their interests relative to other creditors. This coordination "problem" is frequently seen as a weakness of the current system but it is also an important part of the mechanism that makes international lending possible. Proposals to reform the architecture of international contracts often address the costs associated with renegotiating debt, but seldom address the problem that such costs might be necessary to generate international lending in the first place.

An alternative policy intervention is for the debtor government itself to better manage the structure of its liabilities in order to reduce the costs associated with renegotiation following a crisis. First, the government may be able to reduce this time period by carefully choosing its 
creditors or perhaps the nature of credits. If so this will be another important aspect of debt management policy.

The optimal strategy for a sovereign "manager" is to choose a debt portfolio (rather than an optimal contract) that on the one hand makes default unattractive but on the other hand attempts to minimize the damage associated with bargaining that will follow an unavoidable default. The intriguing possibility is that there may be debt structures that ensure a competitive return for investors but inflict less damage to debtors when they are in default. This is possible, in principle, because most of the loss generated by observed debt structures benefits neither party.

There are as far as we know no useful theoretical models of this tradeoff for sovereign $\mathrm{debt}^{8}$. The problem has been carefully analyzed in the context of corporate finance. The problem in both the corporate and sovereign cases is to determine how different numbers or types of creditors affect the optimal debt structure. The corporate case proceeds as follows. All the managers, potential managers, creditors, and potential creditors look forward to the bids that each will make following a seizure of the firm's assets. The composition of debt "matters" under any set of assumptions where the value of the asset to individual participants in this game depends on the behavior of the other participants. Bolton and Scharfstein (1996) assume that new managers earn lower returns on the asset and incur costs of evaluating the assets. In order to distinguish between one and many creditors they also assume that each creditor has the right to seize a well-defined asset and that these assets are worth more when used together than separately. The ability of a creditor to block coalitions that can best utilize the seized asset provides the result that the number of original creditors "matters" for the expected value of the investment to the initial manager.

The structure of the game that determines the equilibrium for different debt structures is quite specific to the assumptions that seem appropriate for corporate finance. These assumptions do not travel well to the case of sovereign debt. But the intuition we want to pursue for the case of sovereign debt does emerge in this model. In general, the government and the corporate "manager" must consider both the contribution of a given debt structure to the probability that a default will occur and the costs of that default should it occur.

Finally, it must be admitted that the behavior of coalitions of creditors that emerge following a sovereign default may be very difficult to predict. The difficulty of evaluating the welfare implications of alternative debt structures is illustrated by the substitution of dollarindexed, short-term debt (Tesobonos) by the government of Mexico for short-term domestic currency debt (Cetes) in the months leading up to the December 1994 crisis. The existing literature on debt management would emphasize the fact that by indexing the liability the government altered its incentives to inflate and devalue the currency. Thus, the probability that a default in the form of inflation and devaluation would be optimal was reduced and this reduced debt service costs.

8 Dooley (1998b) offers a more complete model but is still very far from a framework that would support policy recommendations. 
Our model emphasizes a different aspect of the same policy. The substitution of Tesobonos for Cetes changed the nature of the rescheduling exercise that followed the 1994 crisis. The recontracting in this case was resolved quickly by forceful intervention by official creditors. In retrospect, the issue of Tesobonos was a very good idea if the decision of official creditors, in this case the U.S. government and international organizations, to lend quickly and in large amounts was due to their unwillingness to fight a long costly war with a well organized and a powerful group of holders of Tesobonos. The key assumption that makes the model interesting is that which insures that conflict resolution generates dead weight losses for all the participants. In the corporate finance model outlined above this is a static problem in which the salvage value of the company's assets depends on the structure of debt. For sovereign debt it seems natural to model the dead weight losses that result from the passage of time during which the creditors and debtors argue about the division of future income. During this interval we will assume that the ability to utilize the asset is impaired. Thus we have a problem that is related to the structure of the debt.

\section{Conclusions}

International capital flows have been associated with financial crises in a wide range of developing countries. In this paper we focus on one possible cause of these crises. While it is unlikely that the simple model developed fits all crises. the insurance problem probably contributed to many of these costly episodes.

Some of the conclusions that emerge from the analysis are striking and contrary to lessons drawn from models that do not focus on default. First, there is a coherent argument in favor of entry taxes on all types of capital inflows to countries that cannot effectively monitor domestic firms and intermediaries. The important feature of this type of tax is that it falls disproportionately on investors with short expected holding periods. Reserve requirements or equivalent taxes similar to those imposed by Chile have this feature.

Second, governments of developing countries should avoid financial intermediation even if it appears to promise benefits. Capital gains and losses on the resulting asset and liability structures are likely to trigger capital inflow/crises sequences. It seems to us likely that welfare gains usually associated with financial intermediation are probably quite small relative to welfare losses associated with the larger, and larger variance, portfolios created. An important aspect of this is to limit implicit assets and liabilities associated with exchange rate and lender of last resort commitments. If such commitments are in place, the government should aggressively regulate the behavior of the private sector in order to control the growth of implicit liabilities. For example, to blunt incentives for the private sector to exploit insurance, governments' assets could be immediately used to retire debt.

Third, governments of developing countries should avoid debt and asset structures that needlessly prolong and intensify the decline in economic activity that follows default. A 
"needless" penalty in this context is one that does not efficiently commit the government to repayment ex ante. We are skeptical that such innovations in debt structure can be accomplished through changes in the architecture of international finance although such changes would, of course, be welcome. 
References

Bohn, H., 1988, "Why Do We Have Nominal Government Debt?" Journal of Monetary Economics, Vol. 21 (January), pp. 127-40.

Bolton, Patrick and Scharfstein, David, 1996, "Optimal Debt Structure," Journal of Political Economy, Vol. 104, No. 1 (February).

Bulow, J., and Rogoff, K., 1989, "A Constant Recontracting Model of Sovereign Debt," Journal of Political Economy, Vol. 97 (1), pp. 155-178.

Dooley, Michael P., 1996, "The Tobin Tax: Good Theory, Weak Evidence, Questionable Policy," in The Tobin Tax: Coping with Financial Volatility, Mahbub ul Haq, Inge Kaul and Isabelle Grunberg, eds. Oxford University Press, pp. 83-108.

, 1998a, "Debt Management and Crises in Developing Countries," Prepared for the $11^{\text {th }}$ Annual Inter-American Seminar on Economics, sponsored by the National Bureau of Economic Research and PUC-Rio, December 3-5, 1998.

1998b, "A Model of Crises in Emerging Markets," International Finance Discussion Papers No.630, Board of Governors of the Federal Reserve System, Washington, D.C.

, Eduardo Fernandez-Arias and Kenneth Kletzer, 1996, "Is the Debt Crisis History? Recent Capital Inflows to Developing Countries," World Bank Economic Review, Vol. 10, No. 1, January 1996. pp. 27-50.

Eichengreen, Barry, James Tobin, and Charles Wyplosz, "Two Cases for Sand in the Wheels of International Finance," The Economic Journal, Vol. 105 (January 1995), pp. 162-172.

Fischer, S., 1983, "Welfare Aspects of Government Issue of Indexed Bonds," in Inflation Debt and Indexation, R. Dornbusch and M.H. Simonsen, eds. (Cambridge, Massachusetts: MIT Press), pp. 223-46.

G-22, 1998, "Report of Working Group on Strengthening Financial Systems," October 5.

Stiglitz, J.E., 1983, "On the Relevance or Irrelevance of Public Financial Policy: Indexation, Price Rigidities, and Optimal Monetary Policies," in Inflation Debt and Indexation, R. Dornbusch and M.H. Simonsen, eds. (Cambridge, Massachusetts: MIT Press), pp. 183-222. 


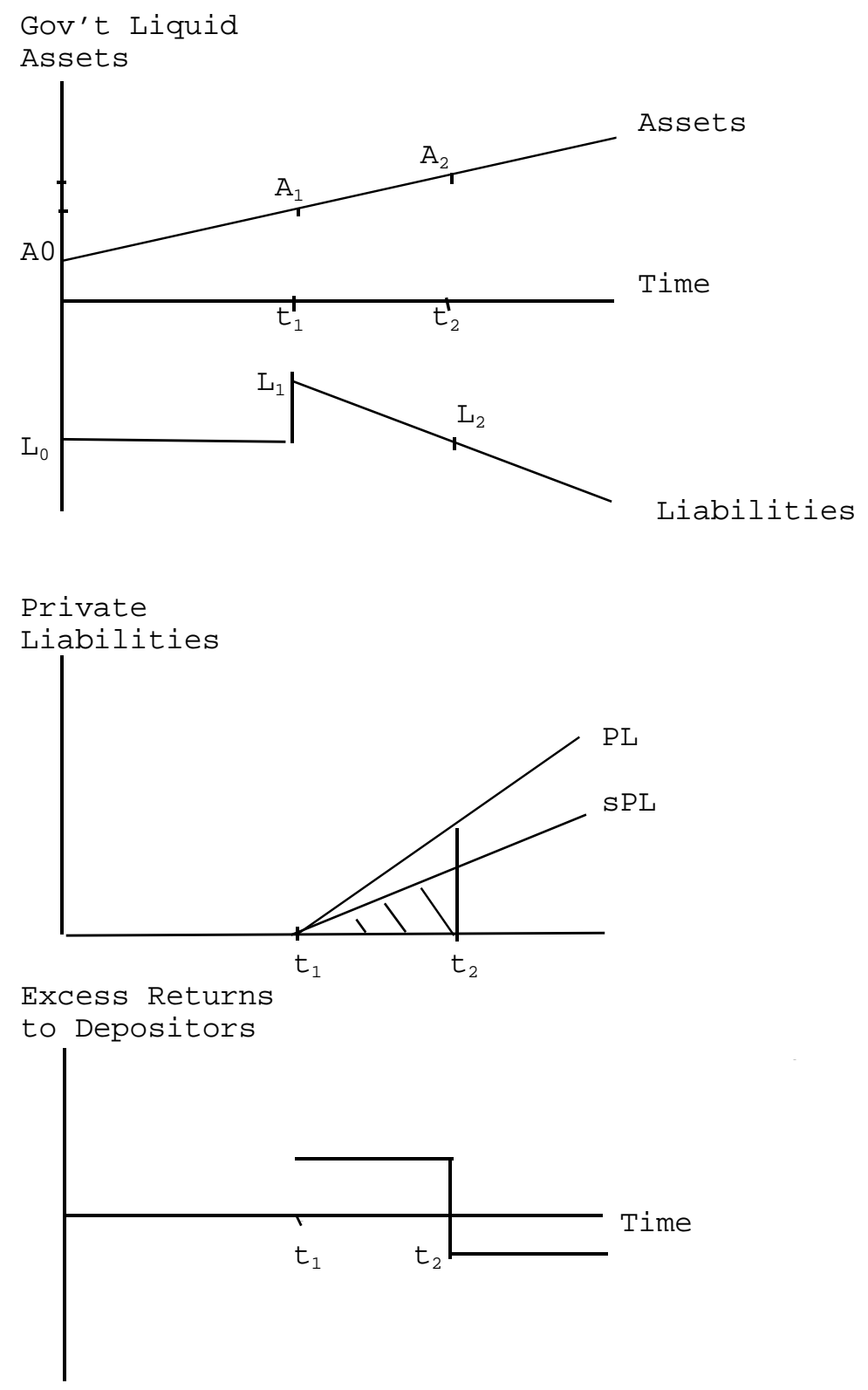

Figure 1: Government Guarantees on Foreign Borrowing 
Figure 2
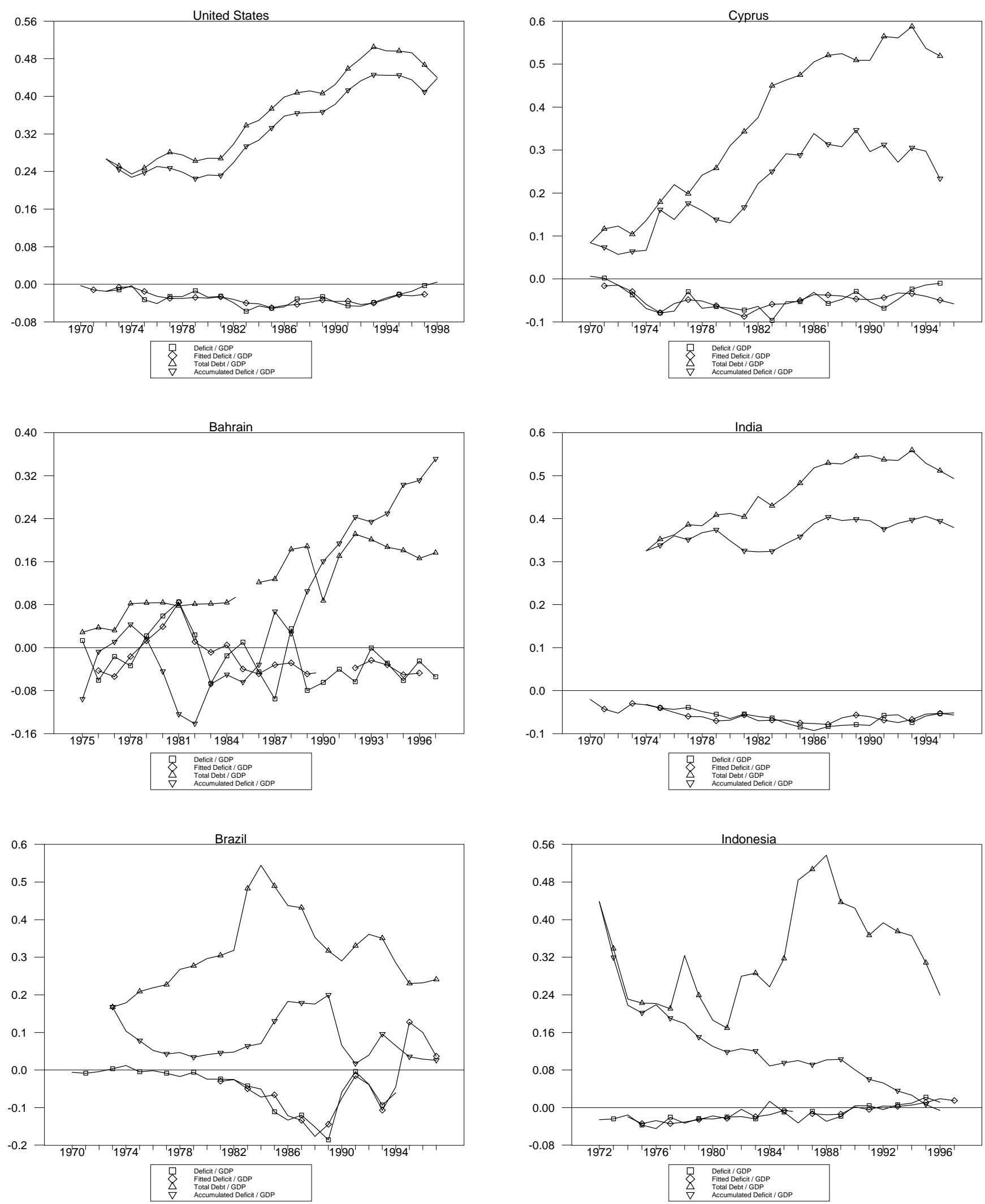
Figure 3
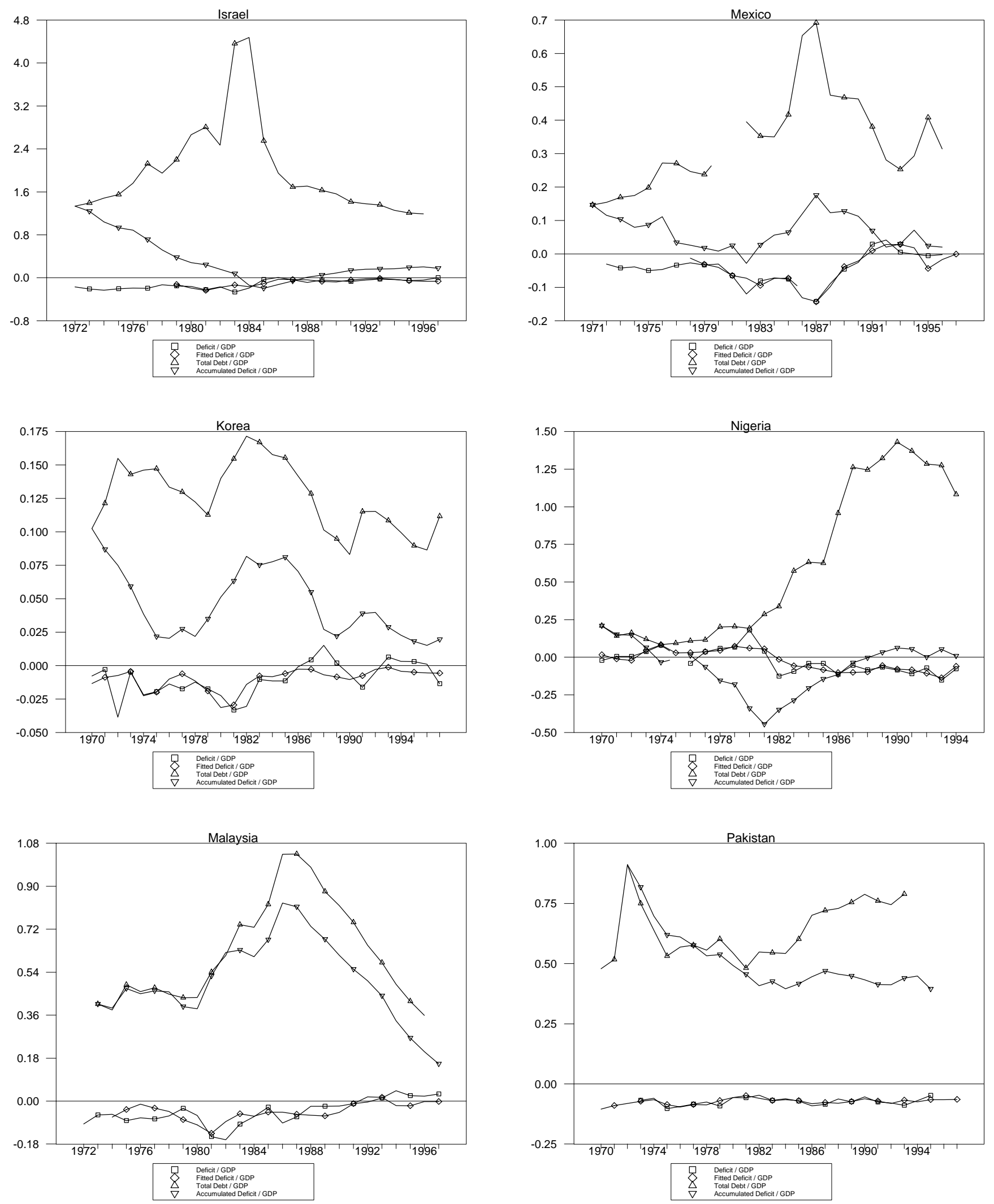
Figure 4
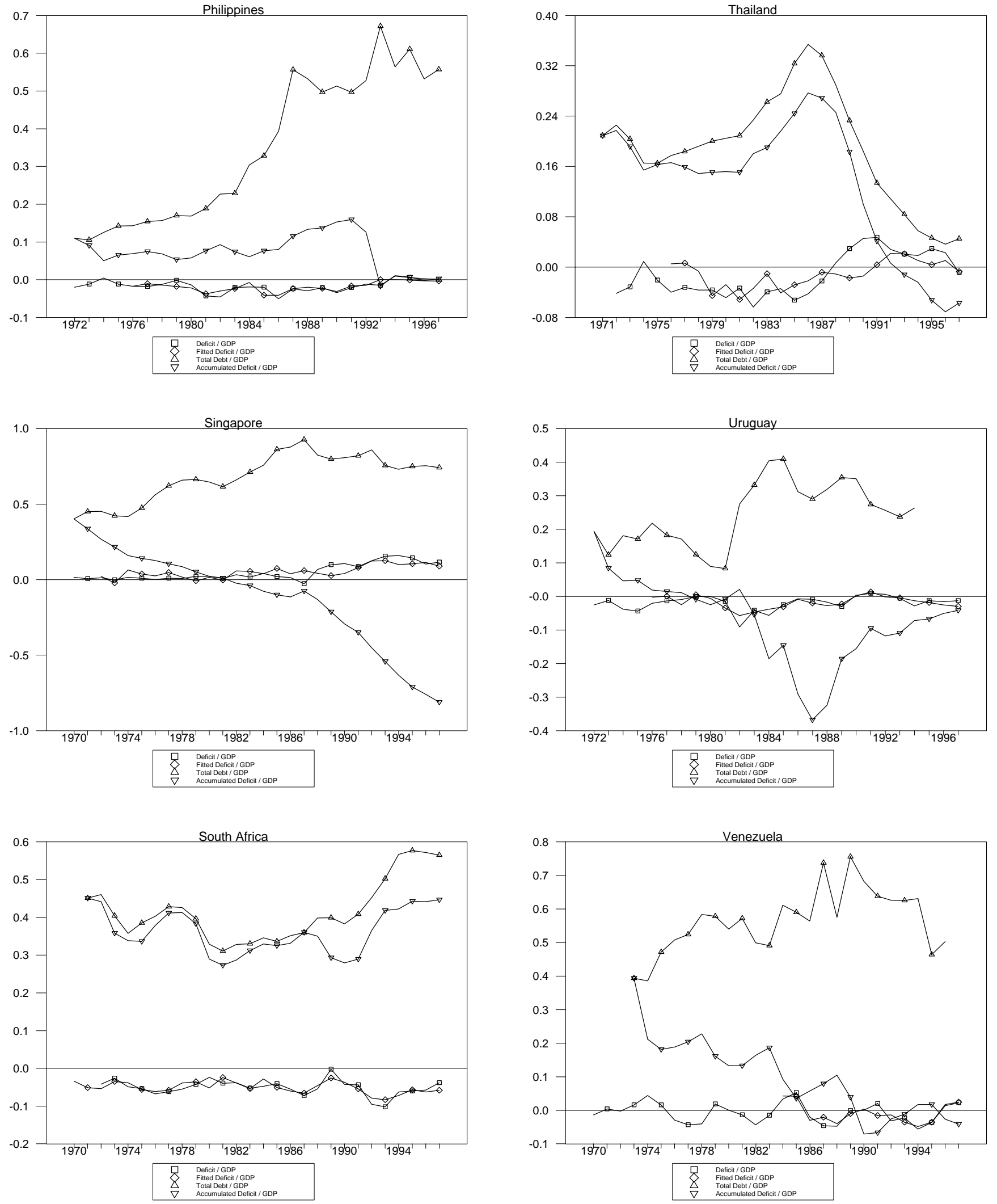